\title{
Role of Gender Equality in Development -A Literature Review
}

\author{
Anne Mikkola \\ University of Helsinki, RUESG and HECER
}

Discussion Paper No. 84

November 2005

ISSN 1795-0562

HECER - Helsinki Center of Economic Research, P.O. Box 17 (Arkadiankatu 7), FI-00014 University of Helsinki, FINLAND, Tel +358-9-191-28780, Fax +358-9-191-28781, E-mail info-hecer@helsinki.fi, Internet www.hecer.fi 


\title{
Role of Gender Equality in Development - A Literature Review *
}

\begin{abstract}
To get a sense of the role that gender equality plays in the process of development and growth, diverse literature is reviewed from microeconomics and macroeconomics and developing and developed country perspective. Some global stylized facts are reported and both empirical and theoretical results are surveyed. Women's roles are found to be in a process of a global change. These changes may stem from changes in technology as the industrialization has made the extensive home-based production obsolete and reduced the demand for children as an input for this production. Instead of the gendered specialization in autarkic households, the modern specialization in the market place may have led to lower fertility and the changing roles of women in the economies. Adjustment to these changes poses challenges globally as the old hierarchical gender valuations still appear in many different disguises. Overall the literature gives hints as to what the issues in gender inequality are that seem to be associated with the overall level of economic development: values and religion, cultural restrictions and roles, legal and inheritance laws and practices, the marital pattern of resource allocation, monogamy vs. polygyny, labor market access, education, fertility, gender specific market failures in finance, power in the political decision making.
\end{abstract}

JEL Classification: O10, J16, J71, D63

Keywords: Gender equality, development, women, segregation, stylized facts.

Anne Mikkola

Department of Economics

P.O. Box 17 (Arkadiankatu 7)

University of Helsinki

FI-00014 University of Helsinki

FINLAND

e-mail: anne.mikkola@helsinki.fi

I want to thank Anna-Leena Asikainen, Basudeb Guha-Khasnobis, Pertti Haaparanta, Marja-Liisa Halko, Seppo Honkapohja, Vesa Kanniainen, Erkki Koskela, Biing-Shen Kuo, Ulla Lehmijoki, Heikki Loikkanen, Carrie A Miles and Maiju Perälä who have read through versions of this manuscript, given suggestions, made me aware of strands of literature, challenged my thinking and/or have been an encouragement along the way. The comments of the participants of the HECER Lunch Seminar, 2005, Nordic Conference on Development Studies in Göteborg, 2004, Kansantaloustieteenpäivät, 2004, the DEVESTU Seminar on Political economy of aid and poverty in Kellokoski, 2004, and the Women Economists Meeting, 2003 are appreciated. 


\section{Introduction}

How might gender equality affect growth and development? Typically, women have globally less economic opportunities to improve their lives. They are often restricted in terms of education, the ownership of wealth, monetary return for their work, financial opportunities, and opportunities to influence the decision making at the level of the family and the society. Given that women are about half of the population and economic potential, it is likely that this situation shows at the macroeconomic level as well. Casual observation indicates that countries in which women and men have more equal economic opportunities are also the more affluent countries. There seems to be some association between level of development and the role of women in the society. As women's status is considered one of the top priorities in development (see UN millennium development goals) research in this field is growing.

Much less attention is paid to men's issues. Jacobsen (2002) points out the importance for development of addressing the specific disadvantages that men face. Much like in women's case there are global problem areas for men, in both developing and developed countries. She reports data on the destruction of human capital that affects men more than women and points out how the changing roles of men put new demands on them. Even if men's restrictions are perhaps more of a self-imposed nature they should be paid attention to and targeted by policy measures. There may be little hope of ultimately addressing women's issues if the men are ignored. As this paper proceeds to review the literature on gender equality mostly focusing on women, it is useful to keep in mind the issues where gender biases show destructively in men's lives.

At the level of macroeconomics, it has been quite difficult to show effects of the status of women on aggregate growth for econometric reasons among others. However, there is more microeconomics literature that might help in understanding how the economic development and growth might be affected by direct or indirect restrictions or exclusion that women have adjusted to. This is a relevant question particularly in the developing countries. Easterly (2001) argues that the continual failures of the western organizations to help the developing countries towards development have been due to the failure to account for the incentives people face. Women in particular face different incentives than men do. Those in the grass root development work generally acknowledge the importance of the status of women in development. The United Nations Millennium Development Goals for example include gender issues among the top 
priorities. United Nations Development Program (UNDP) and the World Bank have also done extensive research on gender and development.

Generally speaking there is a difference between the theoretical and empirical modeling strategies when it comes to the role of gender. Standard economic theories e.g. in public choice or welfare economics do not focus on individual characteristics. The individual actor in welfare economics could equally well be a world citizen, a country national, a man or a woman. As a consequence these theories can be of limited help to policymakers, who are often particularly concerned about the effects of income redistribution on different groups of people, like mothers, single households, families, etc. However, when the welfare economist, public choice economist or labor economist does empirical work, he or she is forced to consider gender as women's behavior differs from that of men to the extent that a single explanatory model is clearly often not applicable. For example, one may estimate party approval rates separately for men and women, or at the minimum one is forced to add a gender dummy to account for the problem. Mostly women are considered separately from men as an empirical necessity rather than issues relating to women being the primary concern. An example of this is seen in the empirical growth studies by Robert Barro, where the effect of female and male education on growth show differently and in a puzzling manner.

Given this split between the theoretical and empirical practice one might ask what has lead to this situation and if it really is that important to be aware of the gender distinction when thinking about the macro level issues. Some insights come from the feminist economics tradition that is discussed in the book edited by Ferber and Nelson (2003). Feminist economists have looked into the common assumptions in economics that are associated with the invisibility of gender and the resulting gender bias in the field. Blank and Reimers (2003) point out that the economists have often been ignorant on the results of other social sciences. For instance, the social norms and behaviors that come from belonging to a particular community tend to be left aside by treating preferences and tastes as given and unchanging. History, however, shows that the institutions and social norms have changed over time and so have the constraints facing women. Psychology, sociology, and anthropology give insights on how the preferences, tastes and desires are formed. The standard method in economics of focusing on choices under given tastes and constraints tends to take the status quo concerning the constraints and tastes as a permanent situation as far as the analysis goes. Economists also tend to emphasize efficiency at the cost of equity as the interpersonal utility comparisons are shied away from. Yet, if we consider women's status as 
important we would need to precisely identify the constraints for women and then study how loosening them would affect the economic choices and equity and thereby development at the macro level. England and Folbre (2003) also point out the lack of consideration in economics for care, which is an important part of women's lives and of any society and its well-being.

Whatever our stance is on feminist economics, we need to be aware of these issues when analyzing the effect of gender on development at the macro level. Indeed, some of the more recent fields of study in economics, like behavioral economics, take some of these challenges more seriously. Another example of risen awareness of the need to consider changing social norms and culture is e.g. a recent book on economics growth by David Weil (2005), which gives considerable emphasis on culture and values.

This paper reviews some of the diverse literature that touches the role of gender in the economy, with the specific focus on issues, which might be expected to be the most critical for overall development. The strategy in the paper is to look at the evidence, data, issues and analysis in the literature covering both the developed world and the less developed world. There is a wide range of differences both in women's status and roles across countries. Likewise, there is a wide range of differences in the level of economic welfare across countries. In some cases, we can also look at how the country's economic development over time is associated with changes in the role of her women. In reviewing the literature, attention is paid to locate where the gender surfaces the economic sphere. Both empirical and theoretical research touching these issues has been done in several areas of economics such as labor economics, family economics, studies on growth, development economics and political economics. 


\section{Stylized facts on gender equality globally}

\subsection{A historical perspective}

When we are talking about women's relatively lower status today, it is useful to remind ourselves of how today's world looks like from the historical perspective. Lagerlöf (2003) suggests that the reason why the economic development spurted in Europe had to do with changes in gender equality over the past 2000 years. These changes were possibly initiated by the spread of Christianity. As opposed to the Greco-Roman world, the early Christians improved the status of widows allowing them to keep her husband's estate and extended women's rights to inherit and hold property. Christian women also got married later.

Towards 1000 A.D. the Roman Catholic Church in Europe took an increasingly negative and ambivalent stance towards women. Evil was seen to come to the world through women, women's sexuality was seen as impure and priests were required to leave their wives and stay celibate. The church had already been establishing its hierarchical structures long ago and along with it women's role got more restricted than in the initial centuries after the birth of Christianity. Reformation did not free women either and consequently some of the traditions from those times still carry on even to the church of today (see Tucker and Leland, 1987). However, the rise of Protestantism may have indirectly been a crucial catalyst for gender equality: Everyone was expected to read the Bible themselves, which led to increased instruction and literacy for girls as well as boys (see Lagerlöf, 2003, for references). This built the basis for women's education and literacy. Perhaps not accidentally, among the very issues that are seen as most critical (e.g. by the World Bank) for the development of today's less-developed countries are girls' education, issues relating to sexuality and fertility, more equitable inheritance laws and practices and increased voice of women in the society (see e.g. the UN Millennium Goals, or the World Bank research).

Indeed we need to go back in time less than a hundred years to find that women still did not have the right to vote anywhere in the now developed world. In the US, the struggle for women's suffrage started in the mid 1800's by Susan B. Anthony and several other women ${ }^{1}$ who joined forces with black men - the latter gaining the right to vote before the white women, who achieved their goal only in 1920. The first country in the world to introduce universal suffrage

\footnotetext{
${ }^{1}$ Incidentally, many of these radical women who fought for suffrage for women and blacks were Quakers, who are known for their egalitarian non-hierarchical beliefs and practices in marriage and church.
} 
was Finland in the 1906 Parliament Act (Source: www.eduskunta.fi). Universities also excluded women until the turn of the century. The first female student was admitted into the University of Helsinki in 1870 - after receiving a special exception of gender. A year later the Massachusetts Institute for Technology admitted its first female student 'as an experiment' (source: Univ. of Helsinki and the MIT web pages).

But what has caused the women's roles to change so dramatically over the past one or two centuries in Europe, the continent where the modern economic growth began over the same time period? Carrie A Miles (2005, 2006), a social psychologist, suggests a technological explanation based on an interpretation of Gary Becker's insights on household specialization. Before the modern production technology households were practically self-sufficient entities where the family patriarch ruled over the servants, the children and the wife. In these autarkic household economies children served as a valuable input to production. For these 'technological' reasons fertility was high and under the scarcity - along the lines of Becker - women specialized in the child bearing and in the production activities at home where the children and the female production activities could be taken care of simultaneously. Men specialized in the jobs that needed to be taken care of outside the home. The industrial revolution was the beginning of a complete change in the autarkic and patriarchal household economy. Much of the domestic production became obsolete as many items could be more efficiently produced in the specialized market place. As this development progressed, children lost their value as direct inputs to production, fertility was lower, and women lost much of their jobs at home. Children became consumption goods instead of production goods. They served e.g. the emotional needs, rather than production needs. This changed the role of women. Specialization within the autarkic household economy became specialization at the market place, and the former gendered nature of specialization was no longer natural or necessary. There was a need for women's roles in the economy to change. Miles sees these technological changes as a cause for the feminism. According to her the historical family structure with male dominion can be understood as based on the woman's ability to bear children rather than on e.g. man's aggression or physical strength. The uniquely feminine ability made her valuable but at the same time made her dependent and most valued only in this specific household. The husband and his household became in practice her employer. Changing employers would be very costly if not impossible. Because of her specialization in domestic labor, she also had little time, training or interest in the things that added to the power men had over each other and over women - war, long-distance trade, finance, politics. This woman had little bargaining power, wealth, property or education within the 
family. The economic and family environment in many developing countries is much like this still today.

Ability to make economic choices requires often earnings and resource ownership. Going forward in time towards the present decades, the feminists of our time have forcefully pursued employment for women. As a consequence, women moved from payless care of children and elderly to do mostly the same work at the market place or for the government. The care work is still today largely women's territory. In a modern welfare state gender hierarchy can be seen e.g. in the gendered segregation of the labor market combined with the fact that the female sectors of the economy are generally less paid and less valued.

\subsection{Some stylized facts of today}

\subsubsection{Status of women}

Globally women's lives more than men's are centered at home. They tend to be more excluded from the society at large. This exclusion can be external as in some developing countries or Arab countries or internal by the women themselves. The societal norms and rules may exclude women from particular types of paid employment or leadership positions. On the other hand men may be excluded from the child care and the home sphere, which is considered the woman's territory. Specialization a la Becker can hardly explain the extent of the resulting segregation and exclusion. This section will survey some of the current statistics available on issues relating to the status of women around the globe.

\section{Education}

Over the past decades there have been large and successful investments globally to extend primary education to all children including girls. In the countries that the UNDP classifies as countries with low human development, female literacy rate ranges between 10-85\% with a typical gender gap (the $\%$ of literate men - the $\%$ of literate women) being around $20 \%$. The higher the incomes and development the smaller is the gender gap (see Figure 2). Globally, this gap has reduced by more than $5 \%$ from 1970 till 1998, with the reduction being more in the lowincome countries. 


\section{Employment}

Over the past 30 years women have increasingly become part of the labor force (see Figure 3). According to the World Bank statistics women's labor force participation as a ratio to men's has increased from about 0.5 to about 0.8 in the high-income countries. In the low-income countries, this ratio has also increased, from 0.6 to 0.7 , while staying at about 0.6 in the middle-income countries.

Women's pay relative to men's in full time employment is reported in Figure 4 for some of the European countries. This ratio varies between 0.7 and 0.9 with a general increase from 1995 to 1997 in all the reported countries (France, Denmark, UK, Finland and Germany).

The quite extreme gender segregation in the EU labor markets is portrayed in Figure 5. Women form about $80 \%$ of the total employment in the service sector while their share is less than $20 \%$ in the industrial sectors in all of these countries.

Overall women's lesser economic resources naturally follow from these facts. Women participate in paid labor force less to begin with. Once they do they are paid about $80 \%$ of the pay that men receive when working full time. Additionally women work more frequently part time, which will of course show in their earnings. Combined with the extreme gender segregation of jobs, it seems obvious that the pay differences are quite stable and not easily to be changed or affected. This is the way the lower economic status shows in the developed world. The financial support that women receive in some countries for taking care of their children is far less than the financial rewards for working for the pay. For the developing countries it is very difficult to get comparable numbers.

\section{Decision making power}

Lack of economic resources is likely to restrict women's economic choices more than men's. Lesser purchasing power translates to lesser decision making power. In developing countries, the laws of inheritance and ownership generally disfavor women more than in developed countries, which may be a significant factor affecting the financial resources women have at their disposal. At the political level women also have less voice. Figures 6 and 7 portray the percentage of women in ministerial and sub-ministerial positions in some developed countries and some developing countries respectively. In most developed countries, women hold 5-15\% of the higher positions with Finland and Sweden being leading exceptions with about a third of the ministerial positions held by women. In developing countries, women frequently hold less than 
$5 \%$ of the higher positions in the society. Overall women participate more in the political and high-level decision making in the developed countries.

Another important decision making power with economic implications concerns the power to decide on one's own body, sexuality and the number of children. Particularly in the developing countries, the customs and norms tend to restrict the choices women are able to make in this respect. High fertility is associated with lesser education for women, less frequent labor market participation outside the home and less economic opportunities. In 1980, the total fertility rate (births per woman) was twice as high globally as in the high-income countries. By 1998 the discrepancy had fallen as the number of children per woman in low income countries had fallen from about six to just above four (excluding China and India). Including China and India, which account for $40 \%$ of the world's population, the average number of children per woman in lowincome countries was three, while the figure for high-income countries was less than two (see Figure 8). A considerable convergence has happened in the fertility of the rich and the poor over the past 20 years. This is bound to influence the roles of women globally in the future.

\subsubsection{Status of men}

Jacobsen (2002) focuses on the men's issues in development and reports detailed country data on areas where men are disadvantaged relative to women. Addressing these issues would work towards gender equality by raising the status of men and through them also women.

\section{Life expectancy}

Some general patterns arise just like in the case of women. Men's disadvantage shows most strikingly in their lower life expectancy by several years. With a few exceptions, men's life expectancy is considerably shorter than women's around the globe. There is a lot of variation across countries but only in some of the poor countries men have equal or longer life expectancy than women. In the majority of the countries, the difference varies from two to seven years in men's disadvantage. The extreme case is Russia where men's expected life span is 12.4 years shorter than women's. The magnitude of the differences clearly is not natural or biological, since men frequent the statistics in human capital destruction - often in the self-imposed form of suicides, violence, occupational injury, substance abuse and diseases of various kinds like HIV/AIDS. 


\section{Changing roles and marginalization}

There appears to be considerable inequality within men in individual countries, which shows in the fact that it is usually the worse off men who become marginalized in the economy. Jacobsen argues that the marginalized men - those e.g. imprisoned, migrating or single may be systematically invisible and omitted from the published statistics. This may correspond to the large numbers of female-headed households and their measured, visible, poverty. Men generally appear to have higher variability in their outcomes than women. Men are disproportionately represented among the high- achievers and the low achievers. This is true in education as measured by grades or test scores and incomes. Again, there is a lot of variation across societies indicating that the variations are not predominantly caused by genetic factors.

Jacobsen has also studied the changing structure of work in the developed countries. Women moved into the labor force beginning in the 1970s. They moved into the growing sectors of the economy, while men were disproportionately in the declining sectors, like manufacturing, mining, and agriculture. Galor and Weil (1996) point out, that men have lost some of the rewards for their comparative advantage in physical strength as the societies have grown to be more capital and knowledge-based since the $19^{\text {th }}$ century. They explain the increase in women's relative wages by developing a model where women and men have equal quantities of brains, but men have more brawn. In a more developed economy the rewards of brains relative to brawn are higher.

\subsection{Measuring gender equality}

Forming a quantifiable measure of the status of women that could be compared across nations is difficult for several reasons. Even within the developed world the role of the welfare state, markets and family differs from country to country. These organizational and cultural differences alone lead naturally to different labor market participation rates, part-time versus full time employment, wage versus transfer payments, childcare arrangements etc. Thus comparing a single economic quantity concerning women across countries may give a misleading picture. Women's work more often than men's is invisible. It is also very difficult to allocate the incomes and consumptions within families to its individual members. The researchers are left with some aggregate measures that describe quantities that are relevant to women. 
To my knowledge there is no single measure or index that would attempt to quantify the status of women relative to men at the global level. The UNDP Human Development report (UNDP, 2003) uses two different indices: the Gender-related Development Index (GDI) and the Gender Empowerment Measure (GEM). They are both based on the human development index $\left(\mathrm{HDI}^{2}\right)$, which is adjusted downwards for gender inequality (see UNIFEM, 2000, p.103). Thus, the GDI and the GEM measure primarily the level of economic welfare in the country rather than women's relative status. GDI falls if the achievement levels of both women and men fall or if the disparity between their achievements increases. GEM examines whether women and men are able to actively participate in economic and political life and take part in decision-making. It is constructed using information on women's purchasing power and decision-making power in the economy and of political power in the parliament.

\section{$3 \quad$ What is meant by gender equality?}

Overall economic welfare and women's welfare are associated. Higher welfare leads to better status for women and visa versa. There is no reason to expect that we would find a one-way causality between women's relative status and development in either direction. Amartya Sen (1999) argues for understanding development as freedom. He suggests that GDP in itself is not the ultimate goal but rather the freedoms associated with it: freedom to exchange goods and labor, freedom to make choices and influence one's life, freedom to live longer, freedom to choose to get education. We can easily understand that slavery, restrictions on owning property, saving or borrowing, or making labor contracts would qualify as disincentives to growth, while freedom to exercise these activities would be associated with economic growth.

The focus of this review is on the channels though which the lower relative status of women might be a hindrance to development. To the extent that women's status is lower relative to men, there are typically some restrictions on freedoms that are directly counterproductive for the future development.

\section{Hypothesis on gender equality and growth}

To focus the discussion that covers the diverse research under review, I propose a simple framework, which is expected to be general enough to apply across nations, cultures and time periods. Gender inequality is thought to show in a hierarchical view of genders, where the men

\footnotetext{
${ }^{2}$ HDI measures the average condition of the people in the country. It incorporates measures of life expectancy, educational attainment and the standard of living.
} 
are above the women, who are considered inferior and less valued by their gender. This involves a hierarchy of power. Gender equality in turn shows in equal value and opportunities for both genders.

Let us begin by looking at some observations on how the gender hierarchy manifests itself in the world today and how it has been modeled by economists. The lesser valuation of girls shows e.g. in the son preference, which appears strikingly in the statistics of newborns in China, India and South Korea. For every 100 girls born at least 9 are missing. Modern technology has offered a reliable method of prenatal sex determination and the option is used increasingly in India and China. In modeling the son preference and marriage patterns Edlund (1999) simply assumes that the parents' utility from a male child is higher than from a girl child. Dahl and Moretti (2004) report surprisingly strong evidence for gender bias even in the US census data. They find that couples with girls divorce more often than couples with boys even if this bias has reduced over time. Also, if a couple has e.g. three daughters, they are more likely to have another child than if they had three sons. They also find that women who take the ultrasound examination and have a girl are 0.37 percentage points more likely not to be married at the time of the delivery than the women who take the examination and have a boy. Andersson et. al. (2004) report a gender bias even in the Nordic countries, which are considered being among the most gender equal in the world. They find the regular son preference in Finland, while in the other Nordic countries they report a daughter preference since mid 1980s. This daughter preference is of the following specific form: If the woman has two sons, she is more likely to have a third child than if she has two daughters. So, it appears to be a possibility that the son preference is turning into a daughter preference as the societal gender systems change.

Generally, the gender hierarchy shows in the family, inheritance laws and customs, the valuations of women's work as opposed to men's work, decision-making power in the society, the family, church and social networks. It shows in the opportunities available for development, education, health and nutrition. It shows in violence and in the general invisibility of the women's work as we will see later on. The hierarchy is generally accepted by both genders and it is not normally questioned.

The exact characteristics of the hierarchical gender valuations differ across countries, but the hierarchy itself exists to different degrees in different cultures. Its existence can be more vividly 
seen when looking at the other cultures in which the practices differ from our own. ${ }^{3}$ The gender hierarchy is not implied by some gender specific specialization, but rather by the restricted opportunities and restricted perspectives for the future that the women's roles typically carry with them. These roles can be prescribed to the women, or taken on by them. The following quote from Amartya Sen gives a perspective to the dynamics by which the hierarchical gender valuations may interact with economics:

'The insecure sharecropper, the exploited landless laborer, the overworked domestic servant, the subordinate housewife, may all come to terms with their predicament in such a way that grievance and discontent are submerged in cheerful endurance by the necessity of uneventful survival. The hopeless underdog loses the courage to desire a better deal and learns to take pleasure in small mercies.' Sen also introduced the idea of capabilities: 'If we do not have the courage to choose to live in a particular way, even though we could live that way if we so choose, can it be said that we do not have freedom to live that way, i.e., the corresponding capability?' (quotes from Sen,1984/1993, - taken from UNIFEM, 2000).

The model by Akerlof and Kranton (2000) can be seen as an explanation of how this hierarchy sustains itself. They introduce identity into economic analysis as a factor that substantially changes previous economic analysis. Identity - person's sense of himself or herself- is incorporated into the utility function as a motivation for behavior, and a simple game-theoretic model is adapted to gender discrimination and social exclusion. Identity is based on social categories C. Each person $j$ has an assignment of other people and himself into these categories $c_{j}$ : men and women in our case. The hierarchy story of the current paper fits directly with the Akerlof-Kranton's idea that the category for women and the associated self-image carries a lower social status. Prescriptions P indicate the appropriate behavior for men and women in different situations. They may also describe an ideal for each gender in terms of physical characteristics and other attributes. The utility function for person $j$ incorporates $j$ 's identity, $I_{j}$, along with the usual vectors of $j$ 's actions, $\mathbf{a}_{\mathrm{j}}$, and others' actions, $\mathbf{a}_{-\mathrm{j}}$ as follows

$$
U_{j}=U_{j}\left(a_{j}, a_{-j}, I_{j}\right)
$$

Person $j$ 's identity is represented as follows:

$$
I_{j}=I_{j}\left(a_{j}, a_{-j} ; c_{j}, \varepsilon_{j}, P\right)
$$

Person's social status depends on the $j$ 's assigned social category, $\mathrm{c}_{\mathrm{j}}$. A person assigned a category with higher social status may enjoy higher self-image. Function $I_{j}($.$) gives the social$

\footnotetext{
${ }^{3}$ E.g. the Muslims see the low status of women in the US, and the Americans see the low status of women in the Muslim countries, yet in both cases women's bodies, naked or covered, are at the focus. Sexual exploitation and violence is common, if not much talked about, in both countries (Franks, 2003).
} 
status of a category. Identity also depends on the extent to which $j$ 's own characteristics $\varepsilon_{j}$ match those assigned to her/his own gender prescriptions P. Finally, identity depends on how well the person's own actions and others' actions correspond to the prescribed behavior, P. E.g. a woman working in a 'male' profession violates the prescriptions for both men and women. Men's identity in the profession may be negatively affected, but also the woman's identity is under conflict.

In the simplest case, the individual $j$ chooses actions to maximize utility (1) taking as given $c_{j}, \varepsilon_{j}, P$ and the actions of others. As in the standard utility theory, people may not consciously realize they are maximizing a utility function like this. Given the complexity with which the hierarchical gender prescriptions, individual characteristics and economic actions interact and enter through identities into the utility functions, it is easier to see why there are difficulties in getting grips with the reasons behind the women's lower status in general when looking at the economic data.

One reason for the continuation of the hierarchical gender valuations seems to be that women themselves actively maintain the lesser value of women by their own behavior. Ben-Ner, Kong and Putterman (2004) conduct a dictator game experiment where women and men are given 100 dollars to be split with a completely unknown person or a person of known gender. Women are found systematically to give less to women than to men or people of unknown gender whereas gender information does not affect men's giving.

The alternative to gender hierarchy is visualized as a situation where both genders have equal opportunities and equal value. This idea shows in the UN declaration of human rights, which was established in 1948. In 1979, the Convention on the Elimination of All Forms of Discrimination against Women (CEDAW) was adopted by the United Nations General Assembly. As of June 2003,174 countries $-90 \%$ of the UN members - are party to the convention. The convention defines discrimination as "any distinction, exclusion or restriction made on the basis of sex...in the political, economic, social, cultural, civil or any other field". Lack of discrimination in this sense could be seen as equal status between genders. As opposed to the hierarchy of power, or separatism where everyone is self-interested and autonomous, the relationship between genders would perhaps need to be described as mutuality, whereby subjects with similar power treat each other with respect and consideration (Nelson and England, 2002). 
The diverse economics literature will be looked at through the above framework with the gender hierarchy and restrictions at the other end of the spectrum and equal value and equal opportunity at the other end. The underlying presumption is that any changes in the status of women in any society show normally in the overall development over longer time period-over decades or perhaps centuries rather than years.

\section{Micro level literature}

If we want to understand the effects of gender inequality at the macro level, we need to look at what happens at the micro level. What kind of market imperfections do women face? How are their incentives for economic activities determined? Can gender inequality in the sense of the hierarchical gender valuations exist with an efficient allocation of resources?

\subsection{Family decisions}

Somewhat curiously, the family economics initiated by Gary Becker ${ }^{4}$ is based on a so called unitary model, which implies perfect pooling: who earns the incomes or owns the economic resources within the family has no implications for the consumption allocations within the family. From the point of view of the family decision-making, it is therefore efficient that the wife specializes in the low pay jobs or the payless homework. The extreme specialization follows from even tiny discrimination on the job market, from the biological differences or comparative advantage in child rearing. The setup does not give women individual decisionmaking powers on their consumption. This is a curious simplification considering that economics in general is all about self-interested individuals making choices under scarcity. In family economics, the unitary model however treats the family as one unit, basically abstracting away issues of power and self-interest: the altruist head of the family has the utility of the wife included within his utility function. Thus the standard household unitary model abstracts away issues concerning the status of women. In the 90's both theoretical and empirical literature has challenged the Beckerian view of the family as the perfect pooling implication seems implausible. There is mounting evidence both in developing and developed countries that men and women would use the family budget differently. An illuminating 'natural experiment' arose in the UK in the late 70's when there was a policy shift that transferred child allowances from husbands to wives. Lundberg, Pollak and Wales (1996) find strong evidence that there was a

\footnotetext{
${ }^{4}$ See e.g. Treatise on the Family (1991) by Becker for a recent exposition.
} 
shift from men's clothing to women's and children's clothing as a consequence. Using African data it is found that income from 'male crops' is used differently from the 'female crops' (see Duflo and Udry, 2003, for references).

On the theoretical side of the literature, Becker's altruist model is interpreted as an ultimatum game with a take-it-or-leave-it commitment structure (Pollak, 2002). To be able to address the decision making within the family, the unitary model has been challenged by modeling marriage as a cooperative bargaining game, where outcomes remain efficient (see Lundberg and Pollak, 1996, for a review). The household unit benefits from various kinds of joint production and scale economies. Bargaining concerns the distribution of these benefits. Spouses negotiate over the distribution within the family, such that the bargaining distribution will depend on the outside options of the spouses. Divorce is sometimes the threat point. In those models, initiated by McElroy and Horney (1981), a policy improving the status of divorced women shifts resources to wives within the marriage. Other models have an internal threat point, a non-cooperative equilibrium, under which the marital responsibilities in the provision of public goods will be allocated according to social norms rather than preferences or productivity differences. In this setup, the policies reallocating income within marriage will change the distribution within the family regardless of the post divorce well-being (see Lundberg and Pollak, 1993). The more general 'collective' model developed by Chiappori assumes efficient outcomes while individuals are free to bargain over the household allocation. The 'collective' model encompasses the cooperative models as well as the model of Becker's as special cases (see Browning and Chiappori, 1998).

Some evidence for the bargaining story comes from looking at dowries as a means of transferring wealth intergenerationally to the daughter. Zhang and Chan (1999) point out that dowry is considered formally as the wife's property, even in the case of divorce. Thus, dowry not only increases the available resources in the new family, but it also increases the bride's bargaining position within the marriage. They show using Taiwanese micro data that a larger dowry increases wife's welfare as measured by the extent of the husband's help in the household chores. A bride-price, which is paid to the parents of the bride, does not have a similar effect.

Interesting insights on how the status of women is associated with the dowry and bride price practices come from the work of Botticini and Siow (2003) and Luke and Munshi (2003). The former paper reviews the historical evidence over thousands of years in different civilizations. It 
is observed that dowries occur primarily in monogamous societies, where married daughters leave their parental home while the sons take over the family business. The authors suggest that altruist parents want to assign large dowries to their daughters while giving their inheritance as a bequest to the sons. This is to mitigate the free-riding problem between the siblings. The role of dowries automatically lessens as the labor markets develop. Dowries were typical for the Eurasian monogamous marriage systems, while bride-prices are practiced in Africa, where polygyny is permitted and practiced. An explanation for the differing practices is given from the relative scarcity of land and labor. In Africa labor was traditionally the scarce resource, and consequently women were valued for both their productive and reproductive capabilities. This may have led to the practice of bride-price. In Eurasia, where land was in short supply, women were primarily valued for their reproductive ability and a dowry system was common (see Luke and Munshi, 2003, for references). These two systems imply a radically different status for women. In the African system, divorce typically leaves the woman with nothing as the husband keeps the children, and the wife's family must return the bride-price. In this setup, the woman has no way to deter extra-marital sexual activity. Luke and Munshi (2003) use survey data on Kenyan men to show that marriage has no effect on sexual activity in this culture. The proportion of married men who reported extra-marital partners in the past year was $45 \%$ as opposed to $5 \%$ in the U.S, while the sexual activity of single men was similar in both Kenya and the U.S. Considering that $80 \%$ of HIV transmission in sub-Saharan Africa is through heterosexual activity, the fact that major parts of populations are infected, and women's inheritance is restricted, there is little to say for economic efficiency in these circumstances.

\subsection{Financial constraints, efficiency and empowerment}

Evidence from studies using developing country data indicates that the allocations of resources between spouses in productive activities are not efficient. Udry (1996) estimates that about six percent of output in agricultural production in Burkina Faso is lost because of inefficient factor allocation within the household: Plots controlled by women are farmed much less intensively than similar plots controlled by men. Duflo and Udry (2003) find, using data from Côte D'Ivoire, that rainfall shocks on different categories of crops (male or female controlled or those whose returns are culturally to be used for joint family consumption) indeed are associated with expenditure shifts within the family. The results reject not only income pooling but also the efficiency in the outcomes. The family members are not insuring each other even against short term variations in individual income. The hypothesis of complete insurance within households is 
thus rejected. Another piece of evidence pointing to economic consequences of women's restricted opportunities comes from the success of micro-finance institutions, like the Crameen Bank, that provide small loans for women to start a business of their own (Armendariz de Aghion and Morduch, 2005).

The loosening of financial constraints appears to be associated with further empowerment of women, particularly when their empowerment is a specific goal in the process. The work by Helzi Noponen (2003) illustrates this interaction quite strikingly. She has developed a method of evaluating the success of the micro credit programs for several large Indian NGOs. Key tool in the ILS (Internal Learning System) is a pictorial diary, which even the illiterate women are able to use to visualize their economic and social situation. The diary is designed to help its users to analyze their livelihood situation, so that they can make strategic decisions about the use of scarce resources available to them. For example, the diary has a picture of a tree where the roots describe the different sources of funds and resources. One side of the trunk has a female face and another side a male face and the branches describe the uses of the income. The woman may e.g. draw a line from an agricultural activity through the woman's side to the male branch denoting alcohol consumption. The diary also has 'dream plots', picturing different possible situations, where the woman again marks her current situation while seeing the path to the better future. The women end up using the diary as to tool to communicate their situation to the authorities and to request resources. It also works in their internal sharing of successes and problems. One of the NGOs adopting the diary, ASA (Activists for Social Alternatives) with about 60000 poor and often illiterate female members, has undertaken a three-year panel study on the effectiveness of their micro credit programs. A random sample of the participants using the diaries was taken to collect more precise quantitative time series. This was done interactively. The interviewer sat down with the woman to ask more precise quantitative questions on the basis of the pictorial diary. The outcomes for long-term members were compared with the outcomes for those who had jointed the program less than two years ago. The results showed that the longer term members in the program were participating more in the household decision-making and the ratio of women owning land and shelter assets alone or jointly with the husband had gone up. Long-term members were also more physically mobile visiting government institutions and speaking out more in public meetings. Compared to short term members, their children had a higher rate of school attendance and greater gender equity. On the negative side, over time loans were increasingly used for consumption and male productive activities, while less investment went to woman's productive activities. Overall the microfinance program and the 
diary, which seems to function as an empowerment too in itself, led to an empowerment of the poor women with an impact on their economic livelihood, living conditions and consumption standards as well as social status and treatment in home and the community.

This overall picture of the role of microfinance in the process of women's empowerment is in harmony with the results from Bangladesh by Pitt and Khandker (1998). They use a careful quasi-experimental household survey design to study the impact of participation in micro finance, by gender, on the labor supply, schooling, household expenditure and assets in Bangladeshi villages. Micro credit taken by the woman rather than the man of the household is found to increase women's non-land assets and children's education. Household expenditures increase twice the amount they would have had the credit been given to the husband. Also men are found to reduce their labor supply if they receive the micro credit, while if the loan is taken by the woman her labor supply is increased (while the man's labor supply is reduced in this case as well). These results appeared considerably larger and more significant for those who participated in the Grameen Bank program rather than the other two major micro credit programs under study. This might seem less surprising given that Grameen Bank was explicitly founded with the purpose of serving women. Muhammad Yunus, an economics professor, recognized the importance of women in development, but it took him 3 years from the beginning of the Grameen Bank in 1983 to increase the share of women from 44 per cent to 75 per cent (see Armendariz de Aghion and Morduch, 2005, for the history). One key to success was that selfemployment activities at home (while attending to the children) were more acceptable than working outside in the Islamic culture that encourages the seclusion of women. Also dealing with the often male program organizer as a group of women was culturally less difficult. Now, 95 percent of the clients are women.

Armendariz de Aghion and Morduch also point out the role of group lending and peer borrowers in deterring domestic violence and providing a way for the women to save by keeping money away from their husbands. In the poor households rising incomes tend to lead to diminishing rather than increasing conflicts between the husbands and wives. From the banks perspective women are found to be better in repaying the loans. Their lesser mobility makes the monitoring of the loans easier. Women, being less mobile and more fearful of social sanctions, are more risk-averse which makes repayment more reliable.

Today the microfinance institutions have spread around the world, e.g. to India, South America and Africa gaining the interest of policy makers, development practitioners and academics alike still targeting globally mostly poor women. 


\subsection{Girls' education}

Studies focusing on developing countries have found girls education particularly important for the welfare of the family and the future development. Many empirical studies conclude that increased schooling of the mother is associated with larger effects on child's health, schooling and adult productivity than increased schooling of the father. (see Schulz, 2001, for references).

Interestingly, there is evidence even in the developed world that it is specifically the mother's education that matters greatly for the children's performance later on in live. Korhonen (2004) finds that the duration of graduate studies in economics, as measured by the time from entering the graduate school to the doctoral defense, is several years shorter for those students whose mothers belong to the better-educated half. ${ }^{5}$ It is curious that mother's education matters so strongly in his sample consisting of the students who have already finished their MA and started their doctoral studies, and even after the general abilities are controlled for. Education of the mothers is found to matter in other studies as well. It is hard to say what lies behind these findings.

Asikainen (2004) finds in her study on party popularities in Finland a curious result indicating that the more educated women consistently disapprove the government more than their less educated sisters (after controlling for other relevant variables affecting party popularities). This result does not depend on what party or coalition is in the government. Corresponding results are not found for men: education does not increase their disapproval rates. One might hypothesize that education makes women more aware of the discrepancy between their ideals and the practice of politics. As it might be more difficult for them to find ways of influencing the decision making, the discontent may turn into general discontent towards governing authorities. It is perhaps not an accident that women's education in many countries faces cultural obstacles. With more educated women, the old power hierarchies of religious, economic and political nature are more likely to be confronted ${ }^{6}$.

\footnotetext{
${ }^{5}$ The study uses survey data on the students who participated in the Finnish Post-graduate Program in Economics, which is a nationwide program coordinating the doctoral studies in economics in Finland. The data consists of 106 students who entered the doctoral program over the years 1991-1999.

${ }^{6}$ See Guiso, Sapienza and Zingales (2003, cited in section 5. 1) for how religiousness is associated with attitudes towards girls' education.
} 


\subsection{Labor market segregation and wages}

In European countries, women earn on average roughly $80 \%$ of what men earn (see Figure 4). A lot of empirical research has been done to identify the magnitude of wage discrimination. These studies use data on developed countries, and the results show that only a relatively small fraction of the wage differences are due to direct discrimination, i.e. paying different wages for exactly the same job to persons of similar qualifications. The finer the classification of occupations and positions, the smaller the discrimination appears to be: with the same title men and women earn almost the same salary. Using detailed data on Finnish industries Luukkonen (2003) finds the discrimination to be $8 \%$.

By far the most significant reason for women's lower incomes on average is the segregation of the job market. This segregation is a more difficult issue for the economist to explain. It is difficult to evaluate the justification of the current situation, where occupations employing women are valued less in terms of pay and prestige.

One potentially useful view comes from the insights offered by the literature on statistical discrimination. Statistical discrimination appears when there is imperfect information on the productivity of a person. Following Lundberg and Startz (1983) lets assume for a moment that the exogenously given distributions of productivities of men and women are identical, but that the observed abilities (OA) (perhaps measured by some 'test scores') are more reliable indicators of the true marginal productivities (MP) for the men than for the women as follows:

$O A_{i}^{\text {WOMAN }}=M P_{i}+\varepsilon_{i}^{\text {WOMAN }}$ and $O A_{i}^{M A N}=M P_{i}+\varepsilon_{i}^{M A N}$,

where $\operatorname{var}\left(\varepsilon^{\text {WOMAN }}\right)>\operatorname{var}\left(\varepsilon^{\text {MAN }}\right)$ and $i$ indicates the individual.

In the competitive equilibrium, each individual is paid according to the expected value of his/her marginal product conditional on the observed ability and the group membership (male or female). It can be shown that the equilibrium wage is a weighted average of mean productivity and the individual's observed ability (or test score). Here the observed ability for the female workers is weighted less because of the greater uncertainty in the observation. Therefore the wage curve facing women is flatter than the wage curve facing men (as shown in Figure 1). 


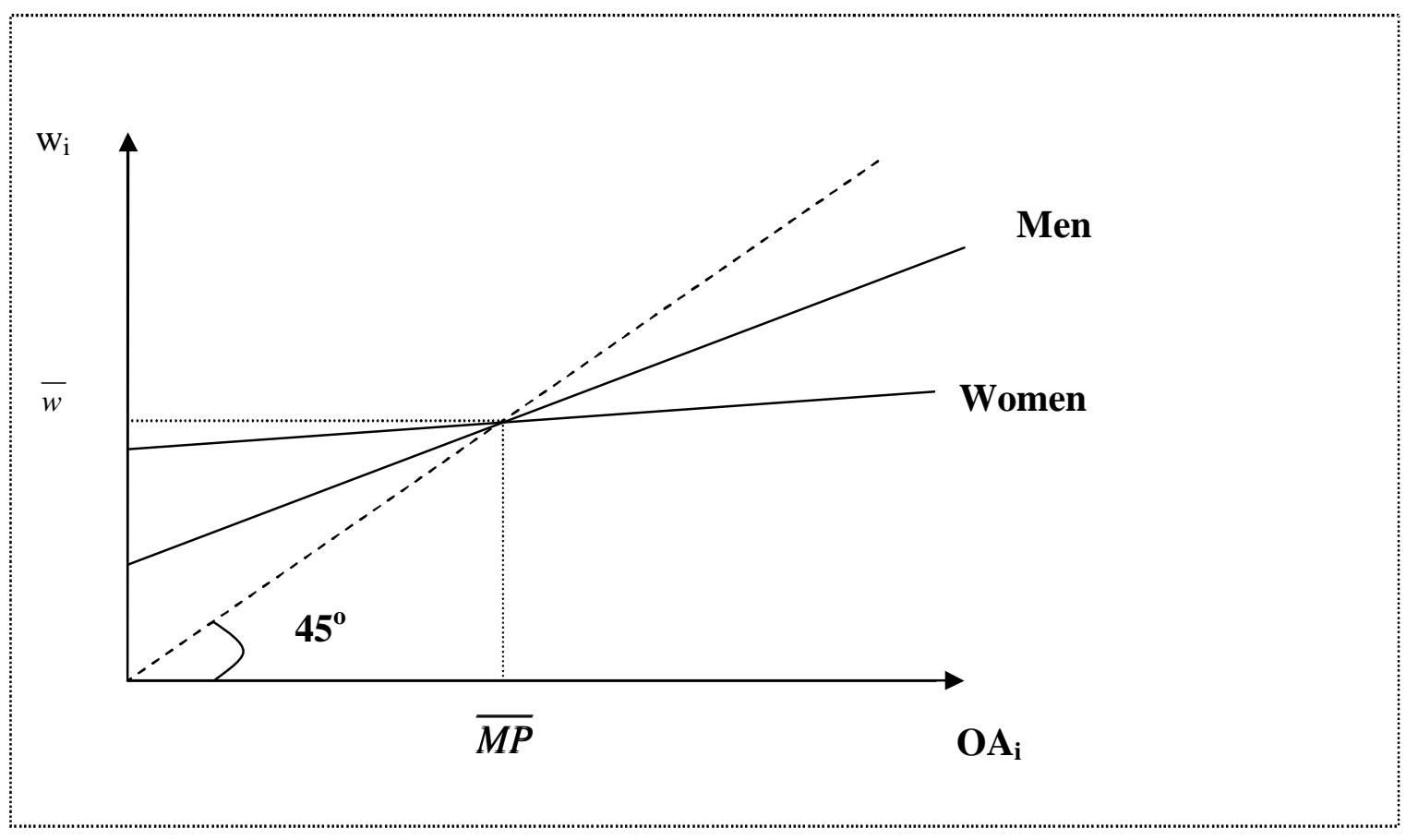

Figure 1. Statistical discrimination

As we can see, women with higher than average marginal productivity are paid less than men with corresponding marginal productivity, and women with lower than average ability are paid more than men with corresponding ability. As men and women get on average the same wage, $\bar{w}$, economists might not want to call this situation discrimination.

Lundberg and Startz (1983) go step further and recognize that the above scenario affects the human capital investments, so that the productivities of men and women are no longer exogenous. If women's wage curve is flatter than men's because their abilities are less precisely observed, this leads to smaller returns to investment in their own human capital. Women will e.g. invest less in activities that lead to promotions. The outcome will be that women's average productivities are less than men's, i.e. less than $\overline{M P}$ in Figure 1. An empirical study might conclude that women's abilities are less and therefore they are paid less on average.

Lundberg and Startz point out that there can be quite large allocative efficiency losses of this kind of discrimination as it becomes unprofitable for women to acquire the required skills, since the investment they make will not be rewarded fully. In this situation, it may be beneficial to prohibit the group-specific treatment of workers. Inefficiency costs associated with such a restriction may turn out insignificant in comparison to the efficiency gains from removing the economic discrimination. Discrimination in this case is defined as a situation where groups of people with equal average initial productive ability do not receive equal average compensation. 
The statistical discrimination problem is likely to be bigger in developing countries, where the statistical odds that educated women will be productive may be very uncertain because of the culture, restrictions, attitudes etc. The first priority of rational parents may be to make sure their sons get educated and become able to support their families, while the daughters are expected to be benefiting from the economic provision of the richer husband. This alone makes it unprofitable for parents to educate their girls regardless of her abilities and talents. Lagerlöf (2003) goes to the extent of explaining the European growth experience over the past 2000 years by the increasing equality in education, which at some point was enough to move Europe to a higher growth equilibrium path. It started to be in the parents' interest to invest in their daughter's productive abilities as the husband (and their sons) where not automatically assigned the task of economic provision in the new equilibrium. This illustrates how difficult it is to gain equality in opportunities in a society which as a whole coordinates to a gender-biased equilibrium. Since this is an equilibrium that serves the societal groups and carries with it certain privileges, it is all too easy to point to its advantages and perceive any changes to it as threatening. At the macro level this shows in less development and slower growth as half of the population is not able to use their abilities fully and the other half is pressed to provide economically regardless of their abilities.

\section{Macro level literature}

\subsection{Growth and status of women}

\section{Growth literature}

Economists have long tried to understand why some countries are poor and some rich, some develop and grow, while others are stagnant. As the research has moved from Solow's growth theories to endogenous growth we are still unable to explain the huge difference in GDP per capita that exists between the many developing countries and the developed world. The growth theory explanations such as faster technological progress, the higher rate of investment and saving, better education, skill levels and infrastructure leave unanswered where these differences come from (see Weil, 2005). The macroeconomics theories have influenced the World Bank and the IMF policies over the decades as these institutions attempted to help the developing countries towards economic growth and development. Easterly (2001) discusses the history of 'solution attempts' that have repeatedly turned out to be disappointments. He explains this by the lack of attention to the incentives that people face. The literature and its prominent authors are currently moving towards explaining the growth discrepancy between the poor and the rich nations by 
factors like social infrastructure (Hall and Jones, 1999), values (Guiso et al., 2002), trust (Knack and Keefer, 1997), religion (Barro, 2002; Dollar and Gatti, 1999) or other aspects of the culture (Weil, 2005). Interestingly in these latest explanations, the role and status of women becomes more visible.

There is also a strong positive correlation between countries' growth rates or GDP levels and gender equality measured e.g. by the ratio of female to male education (see e.g. Lagerlöf, 2003, for a scatter plot of a cross section of countries). The importance of values, attitudes, regional variables and religion suggests that gender inequality may not be an efficient economic choice. E.g. the preference not to educate girls leads to a distortion that prevents the efficient accumulation of human capital. Economy wide values or religion are likely to coexist with market failures, which further contribute to the under-investment in girls. Parents may not invest in girls in an efficient amount as the benefits go predominantly to another family or it may not be profitable to educate girls if they will be discriminated in the labor market either in the form of lesser salaries or by direct barriers to entry. However, if this under-investment is serious it should be visible in the macro data. Becker (1991) points out that even small discrimination or biological differences would lead to complete specialization with the woman specializing in the non-paid homework in the world of perfect pooling between spouses. Even if the perfect pooling within the family is shown not to hold, one may suggest that the combination of cultural values that undervalue women, the inherent patriarchy in many developing countries, biological differences, society wide discrimination and the attached market failures create powerful structures to keep women without voice and economic power segregated to 'home quarters'. This in turn should show at the macro level, even if showing the causality econometrically poses difficulties, which will be discussed later.

To explain macro level growth experience in Europe Lagerlöf (2003) abstracts from differences within genders and intra-household allocation issues. It is assumed that parents care about their own consumption, about the number of their children and the full income of the household into which their children enter through marriage. Parents decide how much to invest in terms of their own human capital (time used) into the human capital of their sons and daughters, which in turn will determine their children's personal income. What matters though is not their child's personal income, but the total income of the child and his/her spouse. The model is shown to have many Nash equilibria depending on the ratio of female to male human capital. If this ratio is low, any individual parent's optimal choice is to invest less in their daughter than in their son, as she is 
likely to marry a wealthier husband in any case. Thus the economy coordinates on a low-genderequality equilibrium. It is assumed that the society over time re-coordinates on a more gender equal equilibria. Consequently, as the ratio of female to male human capital in the society increases there will be a critical threshold after which the economy moves to sustained growth. In the process the parents will be shifting from child quantity to child quality. First mortality and then fertility is being reduced. The model captures the three regimes of Galor and Weil (1999) of the population and income growth in Europe over the past thousands of years.

One of the channels through which gender inequality reduces growth is by reducing the pool of talented people, whose ideas are the ones to lead to technological progress. Esteve-Volart (2000) models this by assuming that the underlying entrepreneurial talents of men and women are evenly and identically distributed. Inequality is modeled by excluding women from the managerial positions. Women are allowed to be only workers. They may choose more primary education to increase their productivity as workers. Any further education does not benefit them because of the exclusion from managerial positions. This form of inequality leads to a fall in the average talent of managers, who are assumed to be the ones coming up with good or bad ideas. The average quality of ideas in the economy in turn determines the increase in technology and growth. In comparison to the version of the model without discrimination, discrimination implies lower female to male schooling ratios, lower wages for both men and women, and lower investment in human capital by both males and females, and reduced growth.

\section{Empirical evidence}

The effect of women's status on growth surfaces in studies where female education is used as one of the explanatory variables in empirical growth regressions (see the series of papers by Barro, 1996, 1997, 1999a; Barro and Lee, 1994, and Barro and Sala-i-Martin, 1995, p. 424). They use annual data from 1960 onwards in about 90 countries, splitting the sample into decades. Thus there is a time series dimension added to the cross sectional data. In the typical regression, the dependent variables are the growth rates of real per capita GDPs over each decade. In the 1997 study for instance, the decades were: 1965-1975, 1975-1985, and 1985-1990. The regression is meant to describe the relation between growth rates and the prior values of the explanatory variables. The choice of explanatory variables is partly justified from the neoclassical growth theory. The level of initial GDP is estimated to have a negative coefficient as expected due to the convergence towards the steady state. Human capital enters the regressions in various forms like the average years of secondary and higher school attainment for males and 
females aged 25 and over and life expectancy. Both variables are observed at the start of the decade. Total fertility is included in most of the specifications as the neoclassical theory implies that the growing population requires more investment to provide capital for new workers ${ }^{7}$. This is where the status of women surfaces and is likely to account for some of the consistently puzzling results and difficulties in the interpretation of the empirical results.

The puzzling result in these regressions is that female education enters either with a negative or insignificant sign while the male educational attainment has a positive contribution to growth rates (for sensitivity analysis see Lorgelly and Owen, 1999). Barro (1997) interprets this by pointing out that female schooling is important for growth through reducing fertility, which is already an explanatory variable in the regressions ${ }^{8}$. Other work has shown that women's education reduces fertility rates. Women's schooling and status seem to appear also through other indicators of economic development like political freedoms. Growth regressions frequently include a variable for political freedoms where a non-linear effect is found: The effect of democracy on growth is increasing as the electoral rights are small but the relation turns negative as moderate amount of rights have been attained (Barro, 1997).

When the reverse channel from economic development to democracy (as measured by electoral rights and civil liberties indexes) is studied, a somewhat surprising result emerges. As opposed to direct growth regressions, the gap between male and female primary schooling now has a negative and significant effect on both indexes (Barro, 1999b). This significance does not disappear if measures of educational and income inequality is included. It is noticeable that it is specifically the early schooling that matters for democratization whereas in the growth regressions the secondary schooling was the significant schooling variable.

Overall, it appears that the effects of the status and schooling of women on growth is hidden behind the other variables like fertility and indices measuring democracy. Barro (1999b, p.167) himself states: 'Perhaps more promising is the idea, reminiscent of Tocqueville (1835), that expanded educational opportunity for females goes along with a social structure that is generally more participatory and, hence, more receptive to democracy.' There also seems to be a relation between country's primary religious affiliation and democracy with Protestant

\footnotetext{
${ }^{7}$ Additional explanatory variables include typically e.g. rule of law index, democracy index, and variables on government consumption and terms of trade.

${ }^{8}$ Since the average fertility rate over the past five years is used as an instrument, he suggests, that the negative coefficient of the fertility rate is likely to reflect the effect of fertility on growth rather than visa versa.
} 
countries being almost always democratic whereas Muslim countries are usually not. Barro suggests that the main effects of religion work through variables like the gap between male and female education. This idea gets more recent confirmation from the study by Guiso, Sapienza and Zingales (2002). They use World Value Survey data, covering 66 countries from 1981-1997, to study the association of religion and economic attitudes. Actively religious people are found to be more intolerant and less sympathetic to women's rights than people who do not belong to any religion or are not actively attending religious meetings. This holds in the major religious denominations (Muslims, Hindus, Jews, Catholics, Protestants and Buddhists). Examples of the survey questions on women are:

- 'When jobs are scarce, should men have more right to a job than women?'

- 'Do you think that women should have children in order to be fulfilled, or is this not necessary?'

- 'A university education is more important for a boy than for a girl'

The association of religiousness and the lesser value given to the women's education and market work is particularly strong in Muslim religion.

There are several empirical studies that specifically focus on the effects of gender inequality on growth (for a summary see Lorgelly, 2000). Particularly, the World Bank has produced research that points to the importance of addressing gender issues for development and growth (Dollar and Gatti, 1999, Klasen, 1999). A problem in the empirical regressions of this type is the endogeneity of both income and inequality and their interdependence. Dollar and Gatti (1999) make an attempt to estimate not only the effect of gender inequality on growth but also to explain how gender inequality can be explained across countries and over time. They use panel data on 127 countries in four 5-year periods over 1975-1990. The estimated equations for the growth and gender inequality are respectively:

$$
\begin{aligned}
& \left(\frac{\dot{y}}{y}\right)_{i t}=\delta+\lambda q_{i t}+X \pi+u_{i t} \\
& q_{i t}=\alpha+\beta_{1} y_{i t}+\beta_{2} y_{i t}^{2}+Z \gamma+\varepsilon_{i t}
\end{aligned}
$$

$\left(\frac{\dot{y}}{y}\right)$ it $:$ per capita income growth

$q_{i t}:$ measure of gender inequality

$\mathrm{X}$ : exogenous variables that affect growth

$\mathrm{Z}$ : exogenous variables that affect gender inequality 


\section{Effects of income on inequality}

Let us first look at the estimation of the latter equation. Gender equality is measured primarily by the female secondary school attainment (the $\%$ of female population over 25 years for whom secondary school is the highest level of attainment), but also alternatively measures of life expectancy, economic or marriage rights are used. The corresponding male variables are controlled for in the regressions. The other variables in $\mathrm{Z}$ measure civil liberties, religion and regional factors. The results show a convex relationship between income and gender equality when controlling for male variables and other explanatory variables. This relationship persists when income is instrumented for by variables that affect income but not gender inequality. A causal relationship appears likely: Increases in income lead to less gender inequality in education. Due to convexity, this effect is minor for countries with lower middle incomes or less, while the effect is kicking in as countries move to higher incomes. The convexity of the relationship is sharper for women than for men and is visible even when looking at the data plots of country incomes and secondary attainments by gender. This relationship holds also for other measures of equality like women's economic equality under the law and women in parliament. Women's rights in marriage on the other hand do not seem to be associated with income.

Differences in cultural preferences stand out as religious and regional variables have considerable explanatory power. Dollar and Gatti suggest that gender inequality is not an efficient economic outcome: religious preferences can lead to slower growth as girls are not educated, or there may be less than efficient investment in girls e.g. because the returns accrue to another family.

\section{Effect of inequality on growth}

In the growth regressions, Dollar and Gatti use the familiar variables from Barro and Lee (1994) as explanatory variables (X): level (and square) of per capita income, black market premium, the rule of law, revolutions, regional dummies, life expectancy, revolutions, and fertility. To address the endogeneity of gender differentials $\left(\mathrm{q}_{\text {it }}\right)$ they use religion variables and civil liberties as instruments for the measure of gender inequality (the male and female educational attainment) in the 2SLS growth regressions. Women's education is likely to increase growth also through reducing fertility, which here is controlled for, and the focus is on the direct effect of inequality on growth. For the developed country half of the data set $^{9}$ the results turn out to be the opposite

\footnotetext{
${ }^{9}$ The division is done on the basis of the female secondary school achievement.
} 
from Barro's: female secondary school attainment has a significant positive effect on growth while the male attainment enters negatively though insignificantly. In the less developed countries case the signs are the same - though insignificant. Dollar and Gatti suggest that the primary difference from the study by Barro and Lee comes from the use of the regional dummy for Latin America. This is because the typical combination of poor growth and high female education in Latin American countries leads to the panel estimation outcome where the poor growth gets attributed to the high female education levels. Quantitatively, the effect of female secondary school education on growth is quite significant in the more developed countries: 1 percentage point increase in the share of adult women with secondary school education implies 0.3 percentage point increase in per capita income growth.

Another problem in estimating the effect of gender inequality on growth concerns the timing of the effects. I do not know of an effort to estimate the time horizon at which improvements in women's status or education would show as GNP growth. Most of the effects might show indirectly after decades as the future generations enter the labor markets. Klasen (1999) sees the importance of extending the time horizon and estimates a cross-section regression treating the period of 1960-1992 as one observation. With the previous notation, the regression could be rewritten as

$$
\left(\frac{\dot{y}}{y}\right)_{i}=\delta+\lambda q_{i}+X \pi+u_{i}
$$

where the dependent variable is the average compound rate of output growth over 1960-92. The explanatory variables, $\mathrm{X}$, include the typical variables (openness, initial per capita income in 1960, and regional dummies) as well as variables for average investment rates, population growth and labor force growth over the entire period. To avoid multicollinearity problems Klasen chooses variables measuring the overall human capital and others measuring the female to male ratio of human capital. The non-gender specific human capital variables are the total years of schooling in 1960 and the annual growth in total years of schooling over the entire period. The variables capturing the gender inequality, $\mathrm{q}_{\mathrm{t}}$, are the female to male ratio of total years of schooling in 1960 and the female to male ratio of the growth in total years of schooling over the entire period. Also the indirect effects of the gender inequality via population and labor force growth and particularly via investment rates are found important both in size and significance. Large portions of growth differences between different areas can be accounted for by the gender differences. Potential simultaneity problems are checked for by splitting the period 
into decades and using only the initial values of the female to male ratio of total years of schooling. As opposed to the results of the study by Dollar and Gatti, the effect of inequality on growth is not weaker in the developing countries. Inequality in education (both variables) appears to matter more in Africa than elsewhere. Klasen additionally confirms that the fertility rate is particularly affected by the inequality in education rather than by the average education.

Effects of gender inequality on growth may be underestimated if the reduced inequality promotes women's activities that are not recorded in the national accounts (Klasen, 1999). Particularly in the developing countries, it may be that most of the economic effects show in the activities that are not recorded. It is estimated that $66 \%$ of female activities in developing countries are not captured by national accounts compared with only $24 \%$ of male activities being left unrecorded (UNDP, 1995:89). This could contribute to the Dollar-Gatti finding that female attainment positively affects growth in the developed countries - these being the countries where more of the female activities are recorded.

\subsection{Homework and growth}

From the point of view of gender equality and development the standard economics models with separate, self-interested and autonomous agents seems inadequate, as they do not consider the care work that needs to be done in the families and society. It is unclear if it is even possible to give economic value for the large burden that care work puts on any society or to design systems that would reward care work sufficiently economically.

The crucial nature of the often invisible work of women for any economy was pointed out by Joel Mokyr (2002). He goes as far as to compare the significance of increasing knowledge and awareness of the importance of cleanliness and sanitation in the $19^{\text {th }}$ century to the effects of the Industrial Revolution. Previously, decease was associated with poverty. Now there was new knowledge about the germs. The new understanding about the role of cleanliness and its diffusion through all the levels of the society led to emphasis on homework. What was women's invisible work (nutrition, childcare and cleaning) was suddenly seen as the top priority. As a result mortality rates were radically reduced towards the end of the $19^{\text {th }}$ century. In this environment it is not surprising that women's labor force participation outside the home remained low over that period. 
In those days, it was also considered to be women's moral and natural duty to do the work of caring unselfishly without the pay. This view was questioned only much later as the economic independence of the developed world women was achieved by women joining the labor market. Even today there are some voices arguing that women should 'naturally' be the ones to carry the burden of care. In response to these voices Folbre (2001) points out that there were extensive outside restrictions and enforcements to maintain the 'natural'. As cultural and legal restrictions have been lifted from women's lives in the western world over the past few decades, women have been freer to pursue their own self-interest and autonomy the way men have been expected to do for centuries. Women cannot be persuaded anymore to stay in their economically and culturally disadvantaged position.

However, there is a problematic consequence arising from the new-found freedom from discrimination as pointed out by Folbre (2001) in her book titled 'Invisible Heart, Economics and Family Values'. Care of children and elderly in families (work that is devalued by the markets) has been reduced: women do much less of the care work, and while men have increased their participation, this increase does not match the reduced input from women. This in turn is bound to have long run effects on the future development of any society if the human capital is adversely affected. If children are not cared for, that is likely to show up in their human capital and capabilities later on. Alfred Marshall, as a professor at Cambridge, seems to have anticipated this 'threat scenario'. He opposed admitting women to study for degrees in the $19^{\text {th }}$ century. He foresaw that if university education was available to women, they would start developing their own capabilities rather than those of their future children (see Folbre, p. 12). Those days, of course, it would not even occur to him to consider the possibility that men would share the burden of care for the children, the elderly or the home.

It is increasingly clear that the rising status of women needs to be coupled with the changing roles and family responsibilities of men for there to be genuine development. Paying attention to men's disadvantaged position elsewhere would seem like one starting point (see Jacobsen, 2002). Currently, literature on gender equality focuses almost exclusively on women. Yet, genuine development must necessarily include co-operation between men and women. 


\subsection{Decision making at the level of the society}

In the policy circles promoting gender equality and women's voice is often seen as a priority in order to reduce poverty. However, as argued by Kanbur (2002), the mainstream economics typically does not consider gender inequalities or decision-making power as an important economic issue. This has partially to do with the type of models being used where the household is considered as a unit with a single and given set of preferences. The standard unitary model (Becker, 1991) implies that, if women were given power to decide at the level of the society, they would make the same decisions as men, since both genders would equally maximize the household income. ${ }^{10}$ Kanbur argues for the inequality of power as being the fundamental inequality, which is behind the lower female achievements. He is by no means the only economist who sees the lack of women's power to decide for themselves, their family, economy and society as a critical issue in development. Sen (1999) argues that the freedoms are not only development themselves but also necessary for economic growth. The whole literature on household bargaining (see Katz, 1997; Lundberg and Pollak, 1993, 1996, 2003; Pollak, 1994) arises from seeing the importance of within household power issues. More immediately the power issues arise in development studies where case studies and empirical observations are used (e.g. Agarwal, 2001; Roy and Tisdell, 2002). In this context, the hindrance to development due to patriarchal property rights is particularly tangible (see Braunstein and Folbre, 2001; Agarwal, 1994). The UNDP and the World Bank also see women's empowerment as a critical issue (UNDP, 2003b). Even when the issue of power is not directly discussed, the inadequacy of the standard models is becoming increasingly acknowledged and alternative models are being developed (e.g. Duflo and Udry, 2003).

Empirical evidence is mounting indicating that women as political decision makers make different choices. Chattopadhya and Duflo (2001) collected a particularly interesting data set on 165 village councils in West Bengal in India. In 1998, one third of all leadership positions of the village councils were randomly assigned for women. These village councils are responsible for the provision of many local public goods. It turned out that the women invested more in infrastructure relevant to the rural women, like water, fuel and roads, while men invested more in education (as they have access to well-paying jobs). Women make different decisions as legislators in the developed world as well (see Thomas, 1991). In the US presidential elections

\footnotetext{
${ }^{10}$ Additionally, there is lack of gender specific data and conceptual problems in considering intrahousehold consumption, incomes and decision-making as well as difficulties in measuring the 'largess' of the gender inequalities in comparison to other inequalities. Gender has two categories while other inequalities are measured in many categories, which makes the comparison of largeness of the issues misleading.
} 
there has been a consistent gender gap around roughly 15 points over the past 20 years with women voting more for the democrats. Lott and Kenny (1999) show that the women's suffrage in the US around 1920 had a significant positive impact on the size of the state government expenditures and revenues. As suffrage was enacted in different years in different states, in some states involuntarily and in others voluntarily, the causality can be dealt with. The most natural explanation given to this gap follows from the lower incomes of women and the uncertainty that follows from the specialization in household skills which will not be rewarded in case of divorce. Thus women benefit more from various government programs. The gender gap has increased since the 70's in the US and in Europe. Edlund and Pande $(2002,2003)$ find quite convincing evidence explaining this widening gap by the decline in marriage (i.e. single parenthood, out-ofwedlock fertility and divorce). If marriage transfers resources from men to women, then the decline in marriage makes men richer and women poorer. Increased divorce risk in the society and the actual experience of divorce are both shown to make women turn towards left both in the US and in Europe. Both men's and women's political preferences are affected in a way that increases the gender gap. Edlund and Pande suggest some reasons behind the decline in marriage: If you consider marriage a contract where women provide sex and children, then the availability of low cost female-controlled contraceptives and legalization of abortion may have led to reduced transfers from men to women in marriage. On the other hand, if the man's role in the marriage is to be the provider, then women's greater labor force participation and earnings would lead to a decline in marriage.

All this evidence seems to point to the importance of power issues for the status of women. As the Pill and the legalized abortions as well as women's labor force participation were seen by the feminists of the time as giving women increased power to decide on their lives, this would seem to backfire by leaving women more than before alone to take care of the children as divorces and cohabiting became more common.

One can see how the hierarchical gender valuations surface in these research results. In the modern developed societies the hierarchical valuations 'bite' as it is the women who end up paying for children in terms of their earnings one way or another (Fuchs, 1989). It has been politically a very slow process for these valuations to change. It is for instance taken for granted that it is the woman's employer who pays for the costs related to maternity leaves or that it is the mother who is absent from her job to care for a sick child. 
How the issues of decision-making and power at the level of the society affect growth is unclear, but it is evident that the gender valuations affect economic outcomes. Dollar, Fisman and Gatti (1999) have shown that higher rate of female participation in government is associated with lower levels of corruption in a cross section of countries. If women's presence in decision making bodies is associated with reduced corruption, this would certainly be a factor worth considering if we are pursuing growth and development. In this vain, it is interesting to note the active nationwide policies introduced to increase women's status in the past in China, India and Korea - countries that have moved towards the richer countries over the past fifty years (Gupta et. al., 2000).

\section{Summary}

What can be said about the role of gender equality in development based on this survey to various fields of study?

First, the current situation in many developing countries is strikingly similar to that of Western Europe roughly a hundred years ago. The development issues of today's developing countries are the same that the now developed countries solved over the past century or two: education for girls, women's political, legal and marital rights, outside the home employment for women and men alike, lower fertility and reduced child mortality.

It can be argued that the immediate push for greater gender equality in the developed countries came through the technological changes that moved the production from autarkic households to the market place. These changes led to a change in the specialization, the function of children and the role of women. Children were no longer needed for production purposes at home nor were women. The organization of household economies, where women specialized in the home production along with child bearing and rearing, became obsolete as more and more of the needed goods were produced outside the home. The economic pressure to have many children disappeared. Instead of production purposes children started to serve consumption purposes. There was a growing need for a change in the role of women in the economy. The required adjustment to these changes has not been quick or easy. It required a profound change in the old patriarchal world where the roles of men and women were distinctly different - women's identity and roles centered on the child bearing (see Miles, 2006, for the development of these 
arguments). Much of these challenges still lie ahead in many developing countries and the process is not finished in the developed world either.

As this paper reviews mostly the current day economics literature, it portrays the issues seen relevant today. The literature illustrates how the hierarchical (or patriarchal) gender valuations appear in very many different disguises. Overall the literature gives hints as to what are the issues in gender inequality that seems to be associated with the overall level of economic development: values and religion, cultural restrictions, legal and inheritance laws and practices, the marital pattern of resource allocation, monogamy vs. polygyny, labor market access, education, fertility, gender specific market failures in finance, power in the political decision making. The challenge in the future is to look at the issues from men's perspective as well. How is the gender inequality adversely affecting men? What are the disadvantages and cultural and economic restrictions that men face? Those restrictions will be different from the ones women face but they may be even more severe in their ways. These restrictions and assumptions about men's roles are being questioned only recently in some societies. There can hardly be a road to real gender equality unless that road is leading to increased well-being for both men and women.

From the policy point of view, it would be important to know to what extent progress is hindered by the societal and economic structures that could be changed by political decisions and to what extent the issue is in the more fundamental valuations and preferences of both genders. From the reviewed literature, it seems apparent that both matter. It further appears that the values are not exogenous to the economic aspects of life. Establishing economic structures and incentives that encourage equality are likely to affect values and customs and visa versa - both working for economic development and growth. It is evident that the causality runs also from economic development to greater gender equality as the economic constraint become less binding: it becomes possible e.g. to send both boys and girls to school. 
Figure 2. Adult illiteracy rate

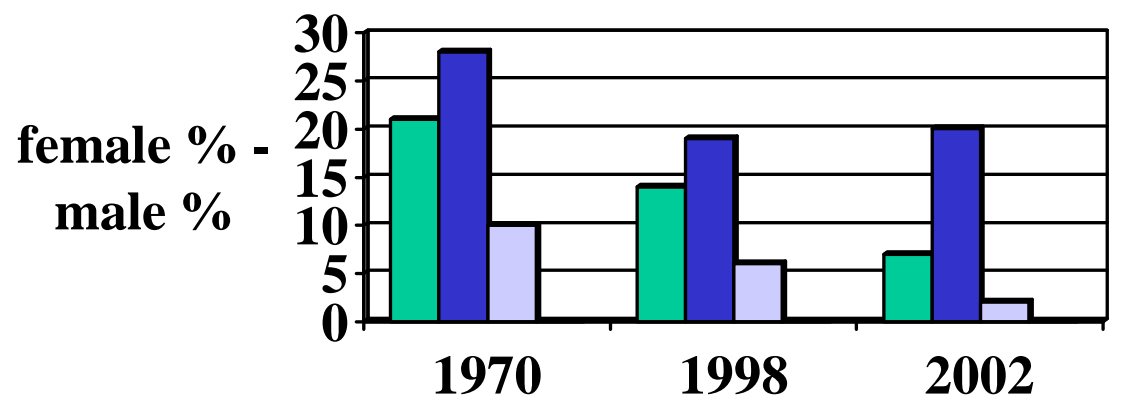

$\square$ World $\square$ Low Income $\square$ Middle Income $\square$ High Income

Source: World Development Indicators, 2000 and 2005, World Bank

Figure 3. Labor force participation rate

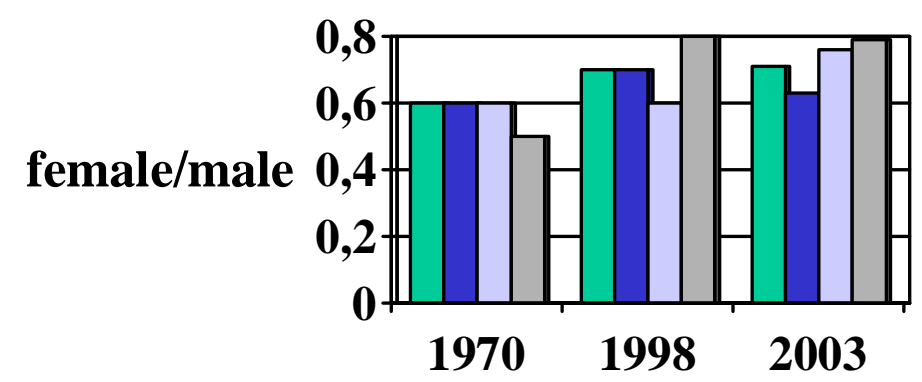

$\square$ World $\quad \square$ Low Income $\square$ Middle Income $\square$ High Income

Source: World Development

Indicators, 2000 and 2005

World Bank 
Figure 4. Women's pay in \% of men's pay, full time

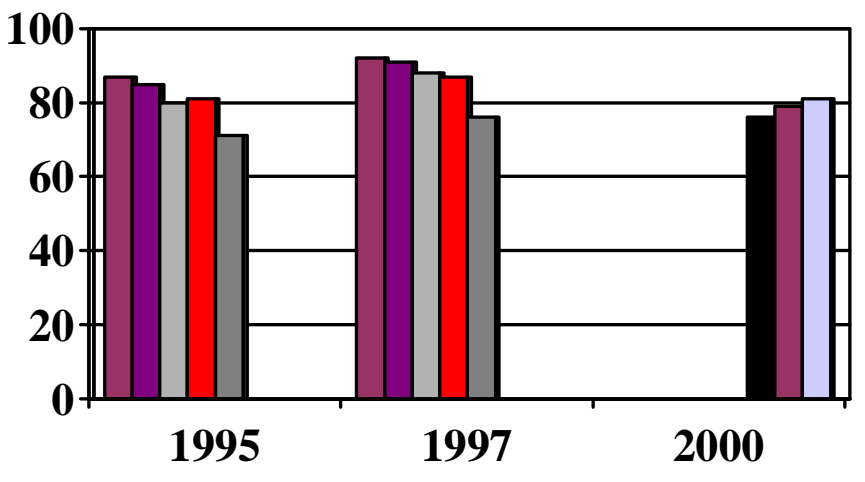

Source:UN/ECE women and men in Europe and North America, 2000

\begin{tabular}{|l|}
\hline$\square$ France \\
$\square$ Denmark \\
$\square$ UK \\
$\square$ Finland \\
$\square$ Germany \\
$\square$ Romania \\
$\square$ Norway \\
$\square$ Poland \\
\hline
\end{tabular}

Figure 5. Gender segregation

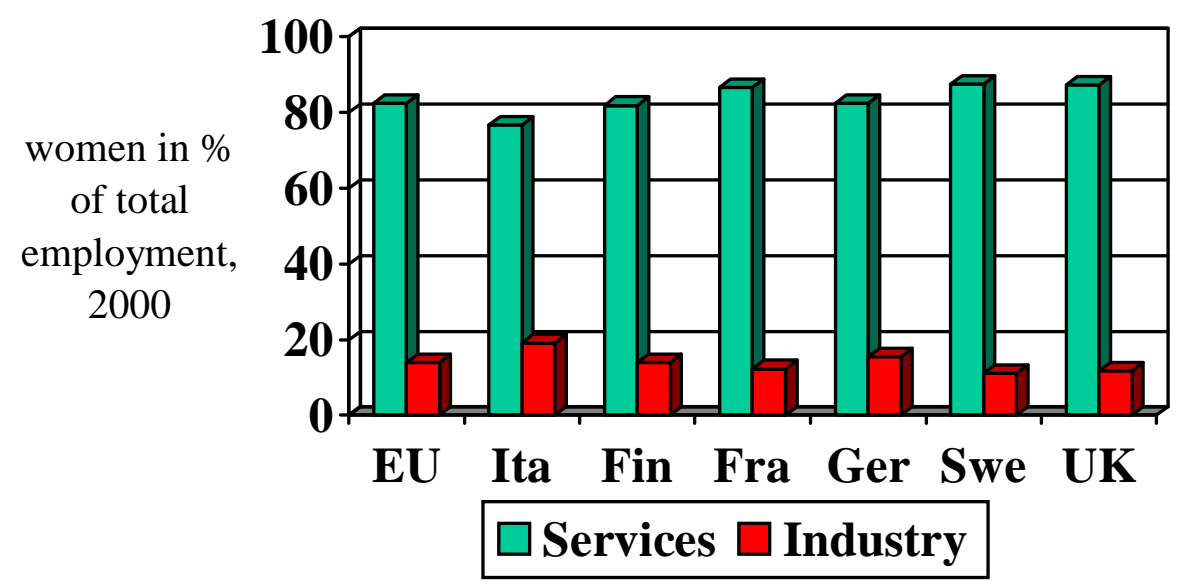

Source: Employment in Europe 
Figure 6. Percentage of women in Government, 1996

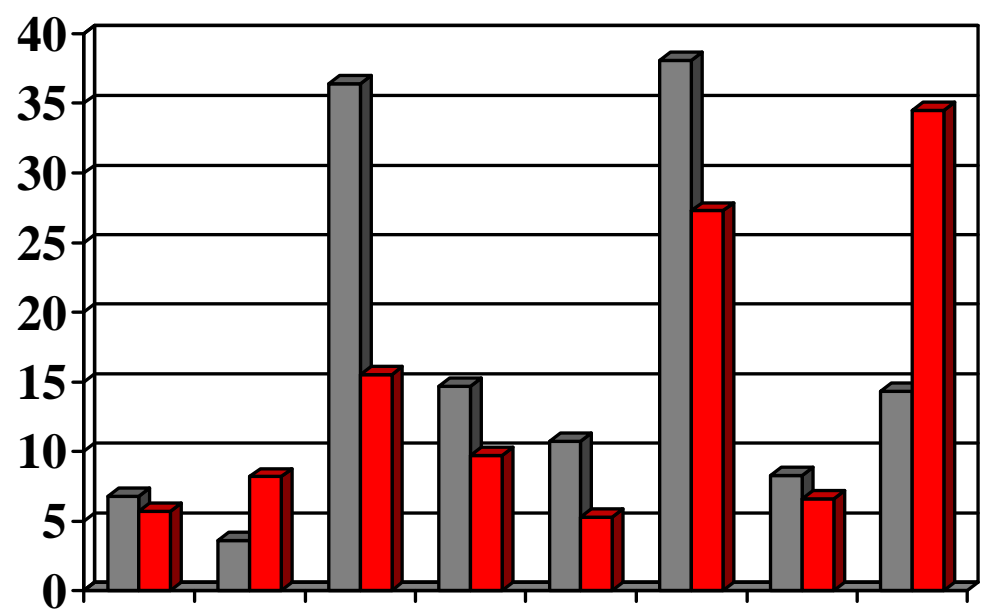

Ministerial

Subministerial

All Ita Fin Fra Ger Swe UK US

Source: www.un.org/womenwatch/daw

Figure 7. Percentage of women in Government, 1996

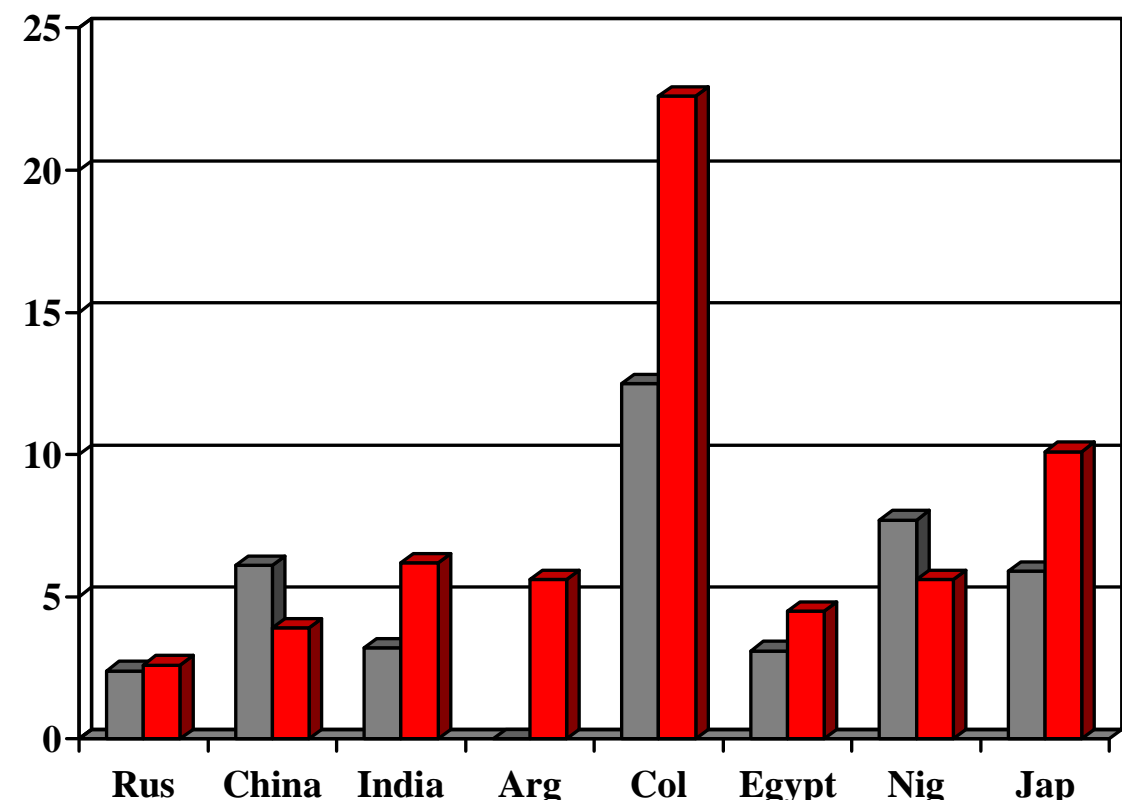

$\square$ Ministerial

Subministerial

source: www.un.org/womenwatch/daw 
Figure 8. Total fertility rate, births per woman

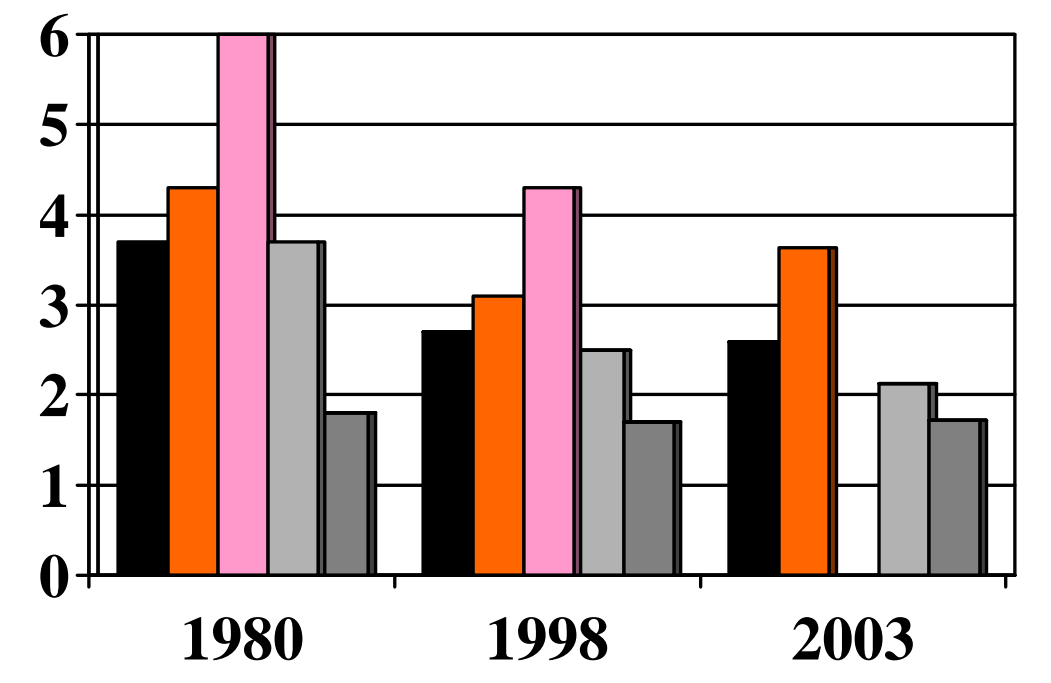

Source: World Development Indicators, 2000 and 2005 World Bank

\begin{tabular}{|l|}
\hline$\square$ World \\
$\square$ Low Income \\
$\square$ excl. China/India \\
$\square$ Middle Income \\
$\square$ High Income
\end{tabular}




\section{References}

Agarwal, Bina (2001), The Hidden Side of Group Behaviour: A Gender Analysis Of Community Forestry Groups, QEH Working Paper Series, No.76.

(1994), A Field of One's Own: Gender and Land Rights in South Asia,

Cambridge University.

Akerlof, George and Kranton, Rachel (2000), Economics and Identity, The Quarterly Journal of Economics, p. 715-753.

Andersson, Gunnar; Hank, Karsten; Ronsen, Marit and Vikat, Andres (2004), Gendering the Family Composition: Sex Preferences for Children and Childbearing Behavior in the Nordic Countries, Max Planck Institute for Demographic Research, Working Paper 2004-016.

Anker, Richard (1997), Theories of occupational segregation by sex: An overview, International Labour Review, Vol. 136, No. 3. (www.ilo.org/public/english/support/publ/revue/articles/ank973.htm)

Armendariz de Aghion, Beatriz and Morduch, Jonathan (2005), The Economics of Microfinance, The MIT Press.

Asikainen, Anna-Leena (2004), Local Unemployment and Other Factors Influencing Individual Government Approval in Finland, University of Helsinki, Department of Economics, Discussion Paper No 608.

Barro, Robert J. (1996), Democracy and growth, Journal of Economic Growth, 1, 1-27. MIT Press. (1997), Determinants of Economic Growth, A Cross-Country Empirical Study, The (1999a), Inequality, growth, and investment, NBER Working Paper No. 7038. (1999b), Determinants of Democracy, Journal of Political Economy, Vol. 107, No.6.

Barro, Robert J. and Lee, Jong-Wha (1994), Sources of economic growth. CarnegieRochester Conference Series on Public Policy 40, p. 1-46.

Barro, Robert J. and Sala-i-Martin, Xavier (1995), Economic Growth, New York, McGrawHill.

Ben-Ner, Avner; Kong, Fanmin and Putterman, Louis (2004), Share and share alike? Gender-pairing, personality, and cognitive ability as determinants of giving, Journal of Economic Psychology 25, p. 581-589.

Blank, Rebecca and Reimers, Cordelia W. (2003), Economics, Policy, and Feminism, in Feminist Economics Today, Beyond Economic Man, eds. Ferber and Nelson, University of Chicago Press.

Becker, Gary (1991), A Treatise on the Family, Harvard University Press. 
Botticini, Maristella and Siow, Aloysius (2003), Why Dowries? American Economic Review 93, No. 4, 1385-98.

Braunstein, Elissa and Folbre, Nancy (2001), To Honor and Obey: Efficiency, Inequality, and Patriarchal Property Rights, Feminist Economics, Vol. 7, No.1, p. 25-44.

Browning, Martin and Chiappori, Pierre-Andre (1998), Efficient intra-household allocations: A general characterization and empirical tests, Econometrica, Vol. 66, No.6, 12411278.

Chattopadhyay, Raghabendra and Duflo, Esther (2001), Women as Policy Makers:

Evidence from an India-Wide Randomized Policy Experiment, MIT Department of Economics Working Paper Series, 01-35.

Dahl, Gordon and Moretti, Enrico (2004), The demand for sons: evidence from divorce, fertility, and shotgun marriage, NBER Working Paper No. 10281.

Dollar, David and Gatti, Roberta (1999), Gender Inequality, Income, and Growth: Are Good Times Good for Women? Policy Research Report on Gender and Development, Working Paper Series, No. 1, The World Bank.

Dollar, David; Fisman, Raymond and Gatti, Roberta (1999), Are Women Really the "Fairer" Sex? Corruption and Women in Government, Policy Research Report on Gender and Development, Working Paper Series, No. 4, The World Bank.

Duflo, Esther and Udry, Christopher (2003), Intra-household resource allocation in Côte D'Ivoire: social norms, separate accounts and consumption choices, Economic Growth Center Discussion Paper No. 857, Yale University.

Easterly, William (2001), The Elusive Quest for Growth, The MIT Press.

Edlund, Lena and Pande, Rohini (2002), Why Have Women Become Left-Wing? The Political Gender Gap and the Decline in Marriage, The Quarterly Journal of Economics, p. 917-961.

Edlund, Lena; Haider, Laila and Pande, Rohini (2003), The Feminization of the Left: Causes and Consequences - Evidence from Europe, preliminary manuscript.

England, Paula and Folbre, Nancy (2003), Contracting for care, in Feminist Economics Today, Beyond Economic Man, eds. Ferber and Nelson, University of Chicago Press.

Esteve-Volart, Berta (2000), Sex Discrimination and Growth, IMF Working Paper, 00/84.

Ferber, Marianne A. and Nelson, Julie A. (2003), Feminist Economics Today: Beyond Economic Man. Press.

Folbre, Nancy (2001), The Invisible Heart, Economics and Family Values, The New Press. 
Franks, Mary Anne (2003), Obscene Undersides: Women and Evil between the Taliban and the United States, Hypatia, Vol. 18, No.1.

Fuchs, Victor (1989), Women's Quest for Economic Equality, Journal of Economic Perspectives, Vol.3, No.1, p.25-41.

Galor, Oded and Weil, David (1999), From Malthusian Stagnation to modern Growth, American Economic Review, Vol. 89, No.2, p. 150-154.

Economic Review, Vol.86, No.3.

(1996), The Gender Gap, Fertility, and Growth, The American

Guiso, Luigi; Sapienza, Paola and Zingales, Luigi (2002), People's Opium? Religion and Economic Attitudes, Center for Economic Policy Research, Discussion Paper No. 3588.

Hall, Robert E. and Jones, Charles I. (1999), Why Do some Countries Produce so Much More Output Per Worker Than Others? The Quarterly Journal of Economics, Vol. 114, No 1, p. 83-115.

Jacobsen, Joyce (2002), What about us? Men's issues in development. Manuscript.

Kanbur, Ravi (2002), Education, Empowerment and Gender Inequalities, Cornell University. www.people.cornell.edu/pages/sk145.

Katz, Elizabeth (1997), The Intra-Household Economics of Voice and Exit, Feminist Economics, Vol.3, No.3, p. 25-46.

Klasen, Stephen (1999), Does Gender Inequality Reduce Growth and Development? Evidence from Gross-Country Regressions, Policy Research Report on Gender and Development, Working Paper Series, No. 7, The World Bank.

Knack, Stephen and Philip Keefer (1997), Does Social Capital Have an Economic Payoff? A Cross-Country Investigation, Quarterly Journal of Economics, Vol. 112, No 4, p. 1251-1288.

Korhonen, Perttu (2004), Tohtorin tekijät, Jatkokoulutuksen tarjontatekijöiden merkitys jatko-opintojen kestossa - elinaika-analyysi. MA thesis, Department of Economics, University of Helsinki.

Lagerlöf, Nils-Petter (2003) Gender Equality and Long-Run Growth, Journal of Economic Growth, Vol. 8, p. 403-426.

Lorgelly, Paula (2000), Are there Gender-Separate Human Capital Effects on Growth? A Review of the Recent Empirical Literature, University of Nottingham, CREDIT Research Paper No. 00/13.

Lorgelly, Paula and Dorian Owen (1999) The effect of female and male schooling on economic growth in Barro-Lee model, Empirical Economics, Vol. 24, p. 537-557.

Lott, John R, Jr. and Kenny, Lawrence W. (1999), Did Women's Suffrage Change the Size and Scope of Government? Journal of Political Economy, Vol. 07, No 6. 
Luke, Nancy and Munshi, Kaivan (2003), What Role Does Marriage Play in Urban Africa? Evidence from a High HIV Area in Kenya, MIT Department of Economics Working Paper 0320.

Lundberg, Shelly and Pollak, Robert (2003), Efficiency in Marriage, Review of Economics of the Household, Sept., p. 153-167.

(1996), Bargaining and Distribution in Marriage, Journal of Economic Perspectives, Vol. 10, No. 4, p.139-158.

(1993), Separate Spheres Bargaining and the Marriage Market, Journal of Political Economy, Vol. 101, p. 988-1010.

Lundberg, Shelly and Startz, Richard (1983), Private Discrimination and Social Intervention in Competitive Labor Markets, American Economic Review, Vol. 73, No 3, p. 340-347.

Luukkonen, Antti (2003), Palkkadiskriminaatio Suomen teollisuussektorin toimihenkilöillä vuonna 2000, Government Institute for Economic Research, Discussion Paper No 309.

Melkas, Helinä and Anker, Richard (1997), Occupational Segregation by Sex in Nordic Countries. An Empirical Investigation, International Labour Review, p. 341-363.

Miles, Carrie A. (2006), The Redemption of Love: Rescuing Marriage And Sexuality from the Economics of a Fallen World, Brazos Press, forthcoming.

(2005), For Richer or Poorer: Materialism's Corruption of Marriage and Family, Past and Present, and Moral Solutions to its Problems." Paper to be presented at Kyambogo University, Kampala, Uganda, Oct. 28, 2005.

Mokyr, Joel (2002), The Gifts of Athena: Historical Origins of the Knowledge Economy, Princeton University Press.

Morduch, Jonathan (1999), The Microfinance Promise, Journal of Economic Literature, Vol. XXXVII.

Nelson, Julie and England, Paula (2002), Feminist Philosophies of Love and Work, Hypatia, Vol. 17, No 2, p. 1-18.

Noponen, Helzi (2003), The Internal Learning system - Assessing Impact While Addressing Participant Learning Needs, Paper presented at the Devestu seminar on Political Economy of Aid and Poverty, May, 2004, in Kellokoski, Finland, available at http://www.enterprise-impact.org.uk/pdf/Noponen.pdf

Pitt, Mark and Khandker, Shahidur R. (1998), The Impact of Group-Based Credit Programs on Poor Households in Bangladesh: Does the Gender of Participants Matter? Journal of Political Economy, Vol.106, no 5.

Pollak, Robert (2002), Gary Becker's Contributions to Family and Household Economics, NBER Working Paper No. 9232. 
(1994), For Better or Worse: The Roles of Power in Models of Distribution within Marriage, American Economic Review, Vol. 84, No.2, p. 148-152.

La Porta, Rafael; Lopez-de-Silanes, Florencio; Shleifer, Andrei and Vishny, Robert (1997), Trust in Large Organizations, American Economic Review, Vol. 87, No 2, p. 333-338.

Roy, K.C. and Tisdell, C.A. (2002), Property Rights in Women's Empowerment in Rural India: A Review, International Journal of Social Economics, Vol. 29, No. = 4, p. 315-334.

Sen, Amartya (1999), Development as Freedom, Anchor Books.

(1997a), Population Policy: Authoritarianism versus Cooperation, Journal of Population Economics, Vol. 10, p. 3-22.

(1997b), Inequality, Unemployment and Contemporary Europe, International Labour Review, Vol. 136, No 2, p.155-171.

Siddique, M.A.B. (1998), Gender Issues in Poverty Alleviation: A Case Study of Bangladesh, International Journal of Social Economics, Vol. 25, No 6/7/8, p.1095-1111.

Smith, Ian (2003), The law and economics of marriage contracts, Journal of Economic Surveys, Vol.17, No 2, p. 201-225.

Schulz, Paul T. (2001), Why Governments should invest more to educate girls, World Development, Vol. 30, No 2, p. 207-226.

Thomas, Sue (1991), The impact of women on state legislative policies, Journal of Politics, Vol.53, No.4, p. 658-976.

Tisdell, Clem (2002), Gender Inequality in India: Evidence From a Survey in Rural West Bengal, International Journal of Social Economics, Vol. 29, No 9, p. 706-721.

Tucker, Ruth and Liefeld, Walter (1987), Daughters of the Church, Zondervan Publishing House.

Udry, Christopher (1996), Gender, Agricultural Production, and the Theory of the Household, Journal of Political Economy, Vol.104, No 5, p. 1010-1046.

UNDP (2003a), Human Development Report 2003, Oxford University Press. (2003b), Millennium Development Goals, Source:

http://www.undp.org/gender/docs/mdgs-genderlens.pdf

UNIFEM Biennial Report (2000), Progress of the World's Women 2000.

Weil, David (2005), Economic Growth, Addison-Wesley Publishing.

Zhang, Junsen and Chan, William (1999), Dowry and Wife's Welfare: A Theoretical and Empirical Analysis, Journal of Political Economy, Vol.107, No 4, p.786-808. 